\title{
UNDERWATER WET REPAIR WELDING OF API 5L X65M PIPELINE STEEL
}

\author{
Grzegorz Rogalski \\ Dariusz Fydrych \\ Jerzy Labanowski \\ Gdansk University of Technology, Poland
}

\begin{abstract}
This paper presents results of the research of effect of polymer insulation of pipeline made of API 5L X65M steel as well as underwater wet welding parameters on properties of joints made by covered electrodes. Effect of heat input on structure and hardness of joints during repair of underwater pipeline was analyzed. Welding defects like microcracks, micro-lacks of fusion, slag inclusions, as well as HAZ hardness increase over an assumed acceptance criterion for welded joints in pipes without anticorrosion polymer insulation, were identified. A significant effect of polimer insulation on structure and properties of welded joints, was found.
\end{abstract}

Keywords: underwater welding, wet welding, underwater pipeline, API 5L X65M steel

\section{INTRODUCTION}

For the mining and operating of crude oil and natural gas resources located under seabed drilling platforms of various design solutions depending on many factors are used. Operation of such platforms is always connected with necessity of drilling the borehole and transporting the stuff. It is possible due to application of pipes of appropriately high mechanical properties. In case of the mining in deep waters both casing column of boring rig and underwater transporting pipelines are usually made of a high strength steels in compliance with rules of American Petroleum Institute (API) as well with ISO standards. These are weldable C-Mn steels or C-Mn steels with small alloying addition of niobium, vanadium or titanium $(\mathrm{Nb}+\mathrm{V}+\mathrm{Ti} \leq 0,15 \%)$ delivered in normalized, quenched and tempered condition or after thermo-mechanical processing. Depending on chemical composition and delivery condition, the pipes show yield strength within the range of $175 \div 830$ $\mathrm{MPa}$. Tab. 1 presents the comparison of basic grades of steels for pipelines in accordance with API 5L rules and ISO 3183 standard.
Tab.1. Grades of steels applicable to pipelines acc. API 5L rules and ISO 3183 standard

\begin{tabular}{|c|c|c|c|c|c|c|c|c|c|c|}
\hline Standard & \multicolumn{10}{|c|}{ Notation of steel grades } \\
\hline API 5L & A25 & A & B & X42 & X46 & X52 & X56 & X60 & X65 & X70 \\
\hline ISO 3183 & L175 & L210 & L245 & L290 & L320 & L360 & L390 & L415 & L450 & L485 \\
\hline $\begin{array}{c}\mathrm{R}_{\mathrm{e} \min } \\
\text { MPa }\end{array}$ & 175 & 210 & 245 & 290 & 320 & 360 & 390 & 415 & 450 & 485 \\
\hline
\end{tabular}

Underwater pipelines are very often protected against aggressive water environment by means of anticorrosive polymer coating. Such protection increases their service life. An excellent example of this technology are pipelines used for pressing water into deposits located $1450 \mathrm{~m}$ deep under Baltic Sea bed and exploited by Baltic Beta platform of Lotos Petrobaltic firm. Because of low pressure in the deposit a water pressing system which increases the pressure and extracts crude oil, was installed. To build such pipelines preinsulated pipes made of X65 API 5L high strength steel are commonly used. 
In spite of many applied precaution systems ocean engineering structures may undergo failures $[1,2]$. The main causes of the failures are the following: corrosion wear, collisions with vessels, excessive operational loads, material defects, fatigue of materials, improper construction as well as workmanship [3-6]. It is usual practice to remove used or failed elements of pipelines and substitute them with new ones. However it is often necessary to repair locally a pipeline by using welding processes. All the repair operations on pipelines with the use of welding or overlaying welding are to meet determined quality criteria. Such criteria concerning underwater welding are given in AWS D3.6M: 2010 requirements. The document determines 3 classes for welded joints made underwater. The class A covers joints with properties close to those produced in the air and is usually applicable to joints produced in hyperbaric dry conditions. The class B was introduced for less-responsible welded joints of a lower permissible value of toughness, greater porosity with possible presence of inclusions in weld - applicable to welded joints produced with a wet method. The class $\mathrm{O}$ - for welded joints operating under low mechanical loading; it contains lower demands in relation to the class B [7].

The wet welding method with the use of covered electrodes is the most commonly applied to underwater welding [8-13]. The technique is characterised by a relatively low cost and possibility of carrying out the welding in situation where application of other methods, e.g. a local dry chamber or dry welding, is either unprofitable or impossible at all [9]. An advantage of wet welding is possible easy operation of welding torch and its drawback is a limited water depth at which a diver- welder is permitted to carry out welding operations. Direct contact of joined elements and electric arc with water contributes to occurrence of welding defects. The greatest problems are due to susceptibility to cracking, especially cold cracking, of welds made underwater $[3,8,10,13$ 17]. High cooling rate of welded joint and associated with it tendency to forming hard quenching structures within the HAZ and increased amount of diffusible hydrogen in deposited metal is conducive to the phenomenon [18-22]. Cold cracking is one of the forms of hydrogen-generated failures of welded joints $[10,17,23]$.

Nevertheless, underwater welding has been for many years applied successfully to repair structures made of low-carbon steels. With appropriately selected welding technology, welds and overlying welds of relatively good mechanical properties can be obtained. More troublesome is the underwater welding of high strength steels with a higher value of carbon equivalent (Ce). Based on many investigations, approximate safety criteria for the wet welding of non-alloy or low-alloy steels, have been determined as follows [21]:

- carbon equivalent for base material: $\mathrm{Ce}<0,30 \%$,

- heat input: higher than $1,5 \mathrm{~kJ} / \mathrm{mm}$.

In case of application of austenitic electrodes value of carbon equivalent of welded steel may be even higher - up to $0,40 \%$. In such situation possibility of the occurrence of hot cracks in weld should be taken into account [21]. An increase in weld plasticity at wet welding can be reached by applying low-alloy electrodes containing nickel. $2 \% \mathrm{Ni}$ content in deposited metal is considered optimum value [24].

Authors $[25,26]$ described repair work carried out on a pipeline of API 5L X65M steel in underwater conditions with the use of the Friction Taper Plug Welding (FTPW) method consisting in drilling the surface layer of damaged pipe and friction welding of holes by using appropriately fitted steel pins.

This work concerns a research which has been undertaken to evaluate if it is possible to conduct underwater repair of a pipeline by using the covered electrode welding method (MMA). Moreover, possible influence of anticorrosive coating of pipeline on weld quality was investigated.

\section{EXPERIMENTAL}

For the experiments two pipe segments of the dimensions: $\phi=102.9 \times 5.7 \times 250 \mathrm{~mm}$ were taken from the water pressing pipeline installed at the underwater crude-oil field (Fig. 1). The specimen $\mathrm{C}$ was covered with an anticorrosive polymer coating of $2.5 \mathrm{~mm}$ in thickness. The specimen $\mathrm{W}$ had metallic surface after mechanical removal of the anticorrosive coating. Over $75 \%$ circumference of the pipes $1.5 \mathrm{~mm}$-deep grooves simulating the repair - demanding defects (cracks, corrosive wear) on pipeline surface, were cut.

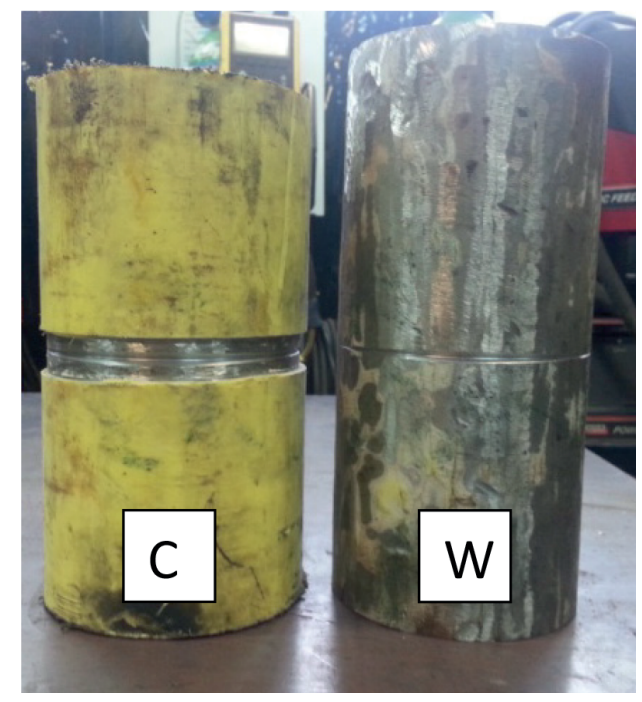

Fig. 1. Specimens prepared to welding. $C$-specimen covered with anticorrosive polymer coating; $W$-specimen without the coating.

\section{MATERIALS USED FOR THE EXPERIMENTS}

The pipeline was made of API 5L X65M steel and to its welding Barracuda E 4621 Ni RR 51 (AWS A5.1: E7014) covered electrodes intended for the underwater welding were used. Chemical composition of the pipes and electrode deposit is given in Tab. 2 and their mechanical properties in Tab. 3. Carbon equivalent was determined according to the formula (1). 
$C E_{\text {IIW }}=C+\frac{M n}{6}+\frac{(C u+N i)}{15}+\frac{(C r+M o+V)}{5}$

Tab. 2. Chemical composition of API 5L X65M steel and weld deposit of $E 4621 \mathrm{NiRR} 51$ electrodes

\begin{tabular}{|l|c|c|c|c|c|c|c|c|c|}
\hline \multirow{2}{*}{ Material } & \multicolumn{8}{|c|}{ Percent weight content of components } \\
\cline { 2 - 11 } & $\mathbf{C}$ & $\mathbf{S i}$ & $\mathbf{M n}$ & $\mathbf{P}$ & $\mathbf{S}$ & $\mathbf{C r}$ & $\mathbf{N i}$ & $\mathbf{C u}$ & $\mathbf{C E}_{\text {IIW }}$ \\
\hline API 5L X65M & Max. & Max. & Max. & Max. & Max. & - & - & - & $\begin{array}{c}\text { Max. } \\
\text { Acc. to the } \\
\text { certificate }\end{array}$ \\
\cline { 2 - 11 } & 0.12 & 0.45 & 1.60 & 0.025 & 0.015 & - & & & 0.43 \\
\hline E 46 2 1 Ni RR 51 & 0.05 & 0.30 & 0.78 & 0.005 & 0.005 & 0.57 & 0.16 & 0.23 & 0.41 \\
\hline
\end{tabular}

Tab. 3. Mechanical properties of API 5L X65M steel and weld deposit of E $4621 \mathrm{Ni} R \mathrm{R} 51$ electrodes

\begin{tabular}{|l|c|c|c|}
\hline \multirow{2}{*}{ Material } & \multicolumn{3}{|c|}{ Mechanical properties } \\
\cline { 2 - 4 } & $\begin{array}{c}\text { Yield point } \\
{[\mathrm{MPa}]}\end{array}$ & $\begin{array}{c}\text { Tensile strength } \\
{[\mathrm{MPa}]}\end{array}$ & $\begin{array}{c}\text { Elongation } \\
{[\%]}\end{array}$ \\
\hline API 5L X65M & $450-600$ & $535-760$ & \\
\hline $\begin{array}{l}\text { E 46 2 1 Ni } \\
\text { RR 51 }\end{array}$ & min. 560 & $500-640$ & min. 20 \\
\hline
\end{tabular}

E $4621 \mathrm{Ni}$ RR 51 electrodes have granted approval for underwater welding, issued by ABS and LRS classification societies. Because of a specific character of water environment the electrodes are additionally covered with a layer which protects electrode coating against absorbing humidity. The electrodes facilitate slag removal after welding, that makes it possible to avoid forming non-metallic inclusions in weld during multilayer welding.

The experiments were carried out with the following plan:

- execution of technological tests of welding in order to determine welding current parameters as well as optimization of angular position of electrode against the pipe,

- underwater wet repair welding,

- non-destructive, visual and penetrating tests,

- macroscopic and microscopic examinations,

- hardness measurements by Vickers method.

One-layer surface circumferential welds were made on test stand intended for the underwater welding up to the depth of about $0.5 \mathrm{~m}$. The surface welds were produced by using covered electrodes of $4.0 \mathrm{~mm}$ diameter, in flat welding position, supplied with direct current electrode negative (DCEN) polarity. The test stand chamber was filled with the artificial sea water (of $13 \%$ salinity) in $20^{\circ} \mathrm{C}$ temperature. Six welded specimens were produced, 3 of them - on the pipes insulated with the polymer coating which was removed over the width of about $20 \mathrm{~mm}$, and 3 - on the pipes without insulation. Three values of heat input corresponding with the minimum and maximum values of welding current appropriate for the applied type of electrodes, as well as the mean value of welding current, were used. The welding parameters are presented in Tab. 4.

Tab. 4. Welding parameters

\begin{tabular}{|c|c|c|c|c|c|}
\hline No. & $\begin{array}{c}\text { Welding current } \\
\mathbf{I}[\mathbf{A}]\end{array}$ & $\begin{array}{c}\text { Arc voltage } \\
\mathbf{U}[\mathbf{V}]\end{array}$ & $\begin{array}{c}\text { Travel speed } \\
\text { Vsp }[\mathbf{m m} / \mathbf{s}]\end{array}$ & $\begin{array}{c}\text { Heat input }{ }^{*} \\
\mathbf{Q L}[\mathbf{k J} / \mathbf{m m}]\end{array}$ & Remarks \\
\hline $\mathrm{C} 1$ & 215 & 28.3 & 3.2 & 1.52 & $\begin{array}{c}\text { Insulated } \\
\text { specimen }\end{array}$ \\
\hline $\mathrm{C} 2$ & 200 & 27.5 & 3.3 & 1.33 & $\begin{array}{c}\text { Insulated } \\
\text { specimen }\end{array}$ \\
\hline
\end{tabular}

\begin{tabular}{|c|c|c|c|c|c|}
\hline No. & $\begin{array}{c}\text { Welding current } \\
\mathbf{I}[\mathbf{A}]\end{array}$ & $\begin{array}{c}\text { Arc voltage } \\
\mathbf{U}[\mathbf{V}]\end{array}$ & $\begin{array}{c}\text { Travel speed } \\
\text { Vsp }[\mathbf{m m} / \mathbf{s}]\end{array}$ & $\begin{array}{c}\text { Heat input* } \\
\mathbf{Q L}[\mathbf{k J} / \mathbf{m m}]\end{array}$ & Remarks \\
\hline C3 & 194 & 28.8 & 3.6 & 1.24 & $\begin{array}{c}\text { Insulated } \\
\text { specimen }\end{array}$ \\
\hline W1 & 215 & 28.3 & 3.2 & 1.52 & $\begin{array}{c}\text { Non-insulated } \\
\text { specimen }\end{array}$ \\
\hline W2 & 200 & 27.5 & 3.3 & 1.33 & $\begin{array}{c}\text { Non-insulated } \\
\text { specimen }\end{array}$ \\
\hline W3 & 194 & 28.8 & 3.6 & 1.24 & $\begin{array}{c}\text { Non-insulated } \\
\text { specimen }\end{array}$ \\
\hline
\end{tabular}

${ }^{*}$ Heat input was calculated according to PN-EN 1011-1:2009 standard

\section{RESULTS OF THE TESTS}

\section{NON-DESTRUCTIVE TESTS}

The visual and penetrating tests were carried out in compliance with the recommendations of PN-EN ISO 17637 and PN-EN ISO 3452-1 standards, $72 \mathrm{~h}$ after completion of welding. As assumed, the welded joints have to meet acceptance criteria for B - quality level according to the requirements of PN-EN ISO 5817 standard, excluding defects of $5^{\text {th }}$ group acc. PN-EN ISO 6520-1, e.g. an excessive weld back reinforcement. No welding defects characteristic for such joints and welding conditions, e.g. weld or HAZ cracks as well as craters or pores, were observed. Local spots of incompletely filled groove were found on the insulated specimen C2 (Fig. 2).

\section{DESTRUCTIVE TESTS}

\section{Macroscopic examinations}

The macroscopic examinations were conducted according to the requirements of PN-EN ISO 17639 standard. Fig. 2 and 3 present macro cross-sections of the surface layer welds.
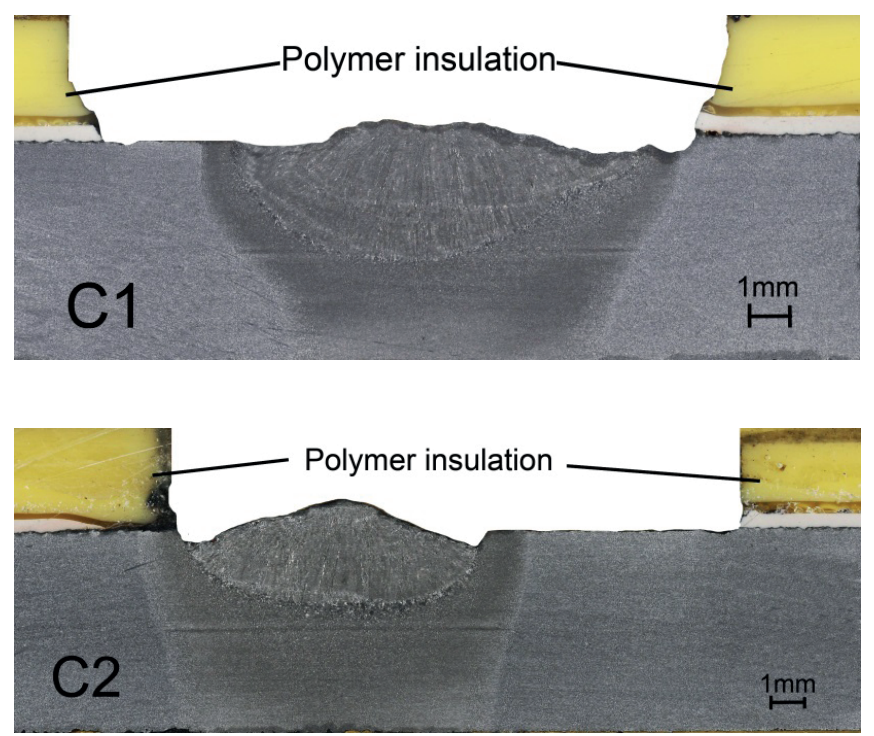


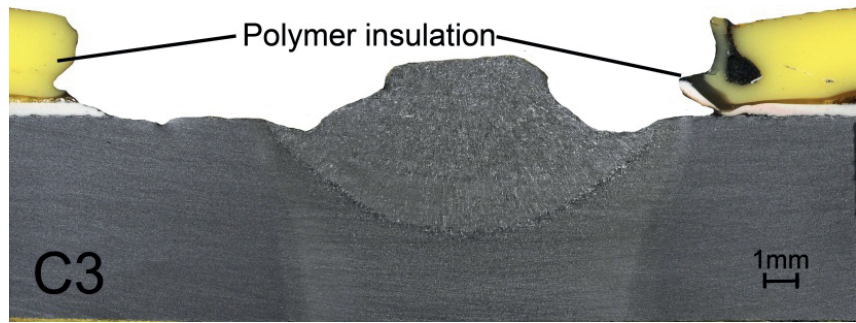

Fig. 2. Macro cross-section of the welded specimens C1, C2, C3 (insulated specimen C). Etch. Nital
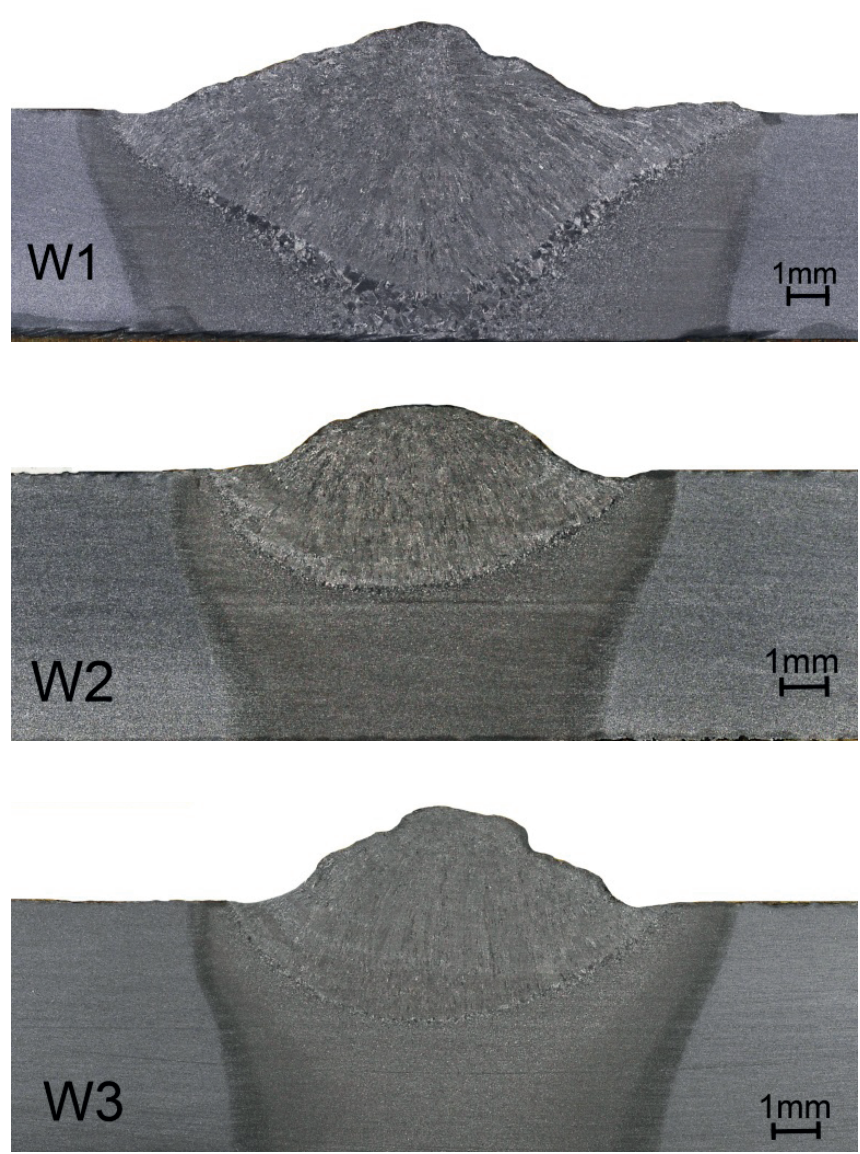

Fig. 3. Macro cross-section of the welded specimens W1, W2 $i$ W3 (specimen without insulation W). Etch. Nital

The specimens presented in Fig. 2 and 3 show full depth of fusion and fully filled groove, only the specimen C2 exhibited undercuts in face of the weld. In case of underwater welding such defects are caused by an improper angular position of electrode against welded element. The remaining joints have a correct, symmetrical structure. On all specimens the wide heat affected zone caused by influence of the water present inside and outside the pipe, can be observed. In the insulated specimens $(\mathrm{C} 1, \mathrm{C} 2, \mathrm{C} 3)$, the HAZ covers a smaller area than in the specimens without insulation (W1, W2, W3). It can be explained by a lower cooling rate of the joint due to presence of polymer coating on pipe surface. The largest fusion penetration was observed in the specimen without polymer coating (W1) where the largest heat input, equal to $1,52 \mathrm{~kJ} / \mathrm{mm}$, was applied.

\section{Microscopic examinations}

The microscopic examinations were performed to reveal structures in characteristic areas of the joints as well as possible microscopic welding defects. Fig. 4 presents of base and weld materials structures. In the base material fine-grain ferrite structure with a low share of pearlite, characteristic for this grade of steel, is observed, whereas the weld has a dendritic structure with column arrangement of ferrite and quasi-pearlite.

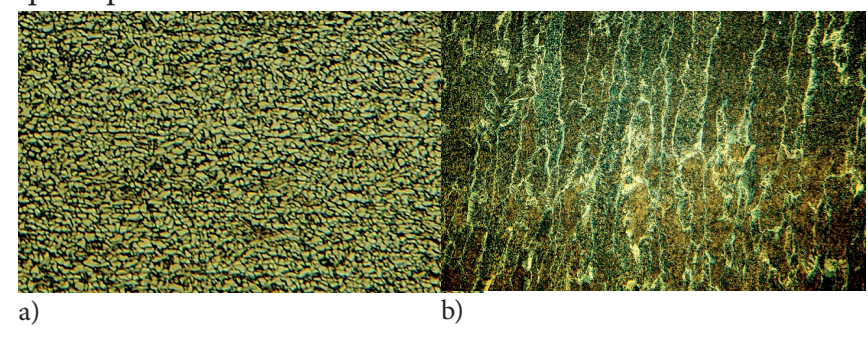

Fig. 4. Microstructures: a) base material of API 5L X65M steel, b) weld area. Magn. $100 x$

In the welded joints in insulated pipes no cracks were found. Fig. 5 shows microstructures along fusion line of the joints. There are visible characteristic areas: the dendritic structure of the weld, coarse-grain structure of the HAZ, normalized area of the HAZ, as well as the structure of the base material. As can be observed, in HAZ microstructure of the $\mathrm{C} 1$ specimen made with the highest value of heat input the biggest grains were formed close to the fusion line, Fig. $5 \mathrm{a}$. In the remaining joints ( $\mathrm{C} 2$ and $\mathrm{C} 3$ ) size of the grains in the HAZ is significantly smaller, Fig. 5b,c.

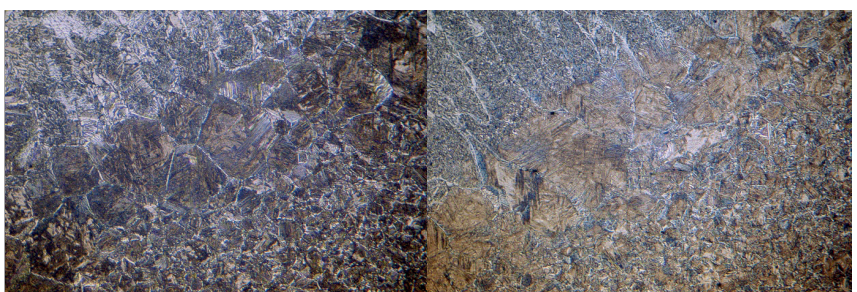
a) Microstructure of the specimen b) Microstructure of the specimen
C1, magn. $x 200$,

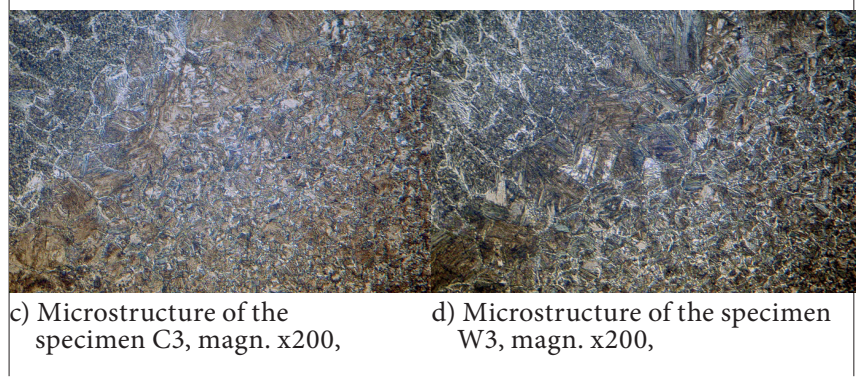

Fig. 5. Microstructure of HAZ in the joints where no cracks were found; a) the specimen $C 1, b$ ) the specimen $C 2, c)$ the specimen $C 3$; d) the specimen W3, magn. $x 200$ 
The tests revealed presence of trans-crystalline cracks in the HAZ microstructure of the specimens without insulation (W1 and W2), Fig. 6. They are characteristic cold cracks which are formed at high cooling rate of the joint in the conditions of stress and diffusible hydrogen occurrence. In both the specimens the cracks propagated along the fusion line: in the specimen $\mathrm{W} 1$ - across the area of bainitic structure (Fig. 6a), and in the specimen W2 (Fig. 6b) the crack occurred in the coarse-grain area of the HAZ. In the specimen W3 welded with the lowest value of heat input no cracks were found (Fig. 5d).

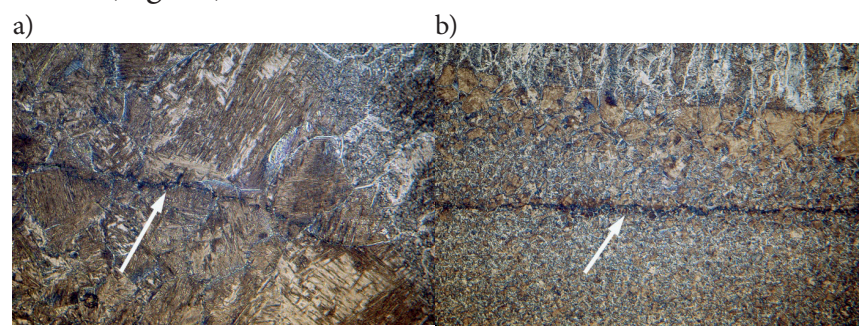

Fig. 6. Cracks occurred in the HAZ of the specimens : a) W1, magn. $x 200$; b) W2, magn. $x 100$

\section{MEASUREMENTS OF HARDNESS}

The hardness measurements were conducted on the cross-section of tested joints by using the Vickers method in accordance with the recommendations of PN-EN ISO 9015-1 standard. Value of the loading force was set on the level of $98 \mathrm{~N}$ (HV10). The measurements were performed at $2 \mathrm{~mm}$ distance from the upper and lower edge of the specimen, Fig. 7. The distance between centres of indents was not smaller than $1 \mathrm{~mm}$. Fig. 8 and 9 show results of the tests.

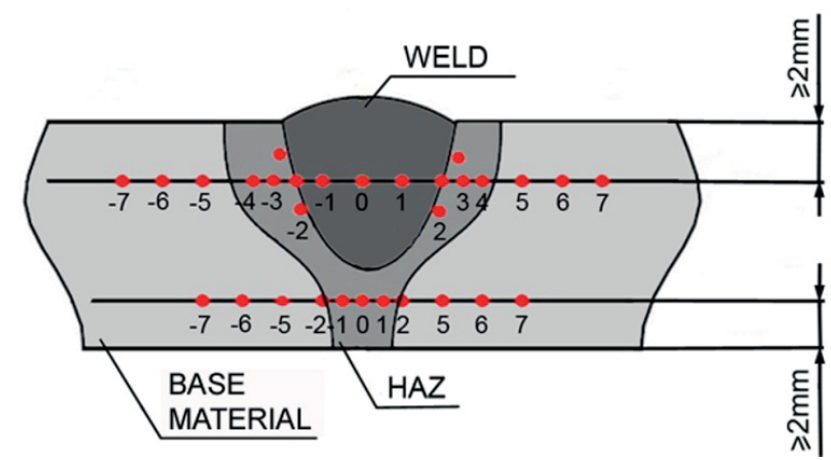

Fig. 7. Distribution of hardness measurement points on the cross-section of welded repair joints

The hardness acceptance criterion for the tested joints was taken equal to $350 \mathrm{HV} 10$ on the basis of the DNV-OS-C401 Offshore Standard (Fabrication and testing of offshore structures). Maximum hardness values of the HAZ in the insulated pipe specimens amounted from 300 to $318 \mathrm{HV} 10$, hence the values were distinctly lower than the acceptance one equal to $350 \mathrm{HV} 10$. In the specimen W1 (without insulation) an excessive increasing of the maximum hardness in the HAZ, up to the level of $386 \mathrm{HV} 10$ and $385 \mathrm{HV} 10$ for the upper and lower measurement line, respectively, was observed. In $\mathrm{HAZ}$ of the subsequent specimens without insulation coating (W2 and W3) the maximum hardness values equal to 343 and $353 \mathrm{HV} 10$, respectively, i.e. close to that of the selected criterion, were measured.

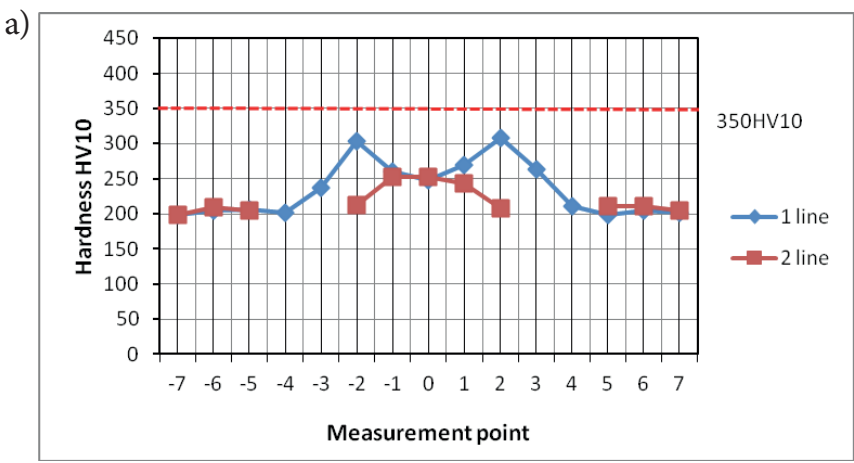

b)
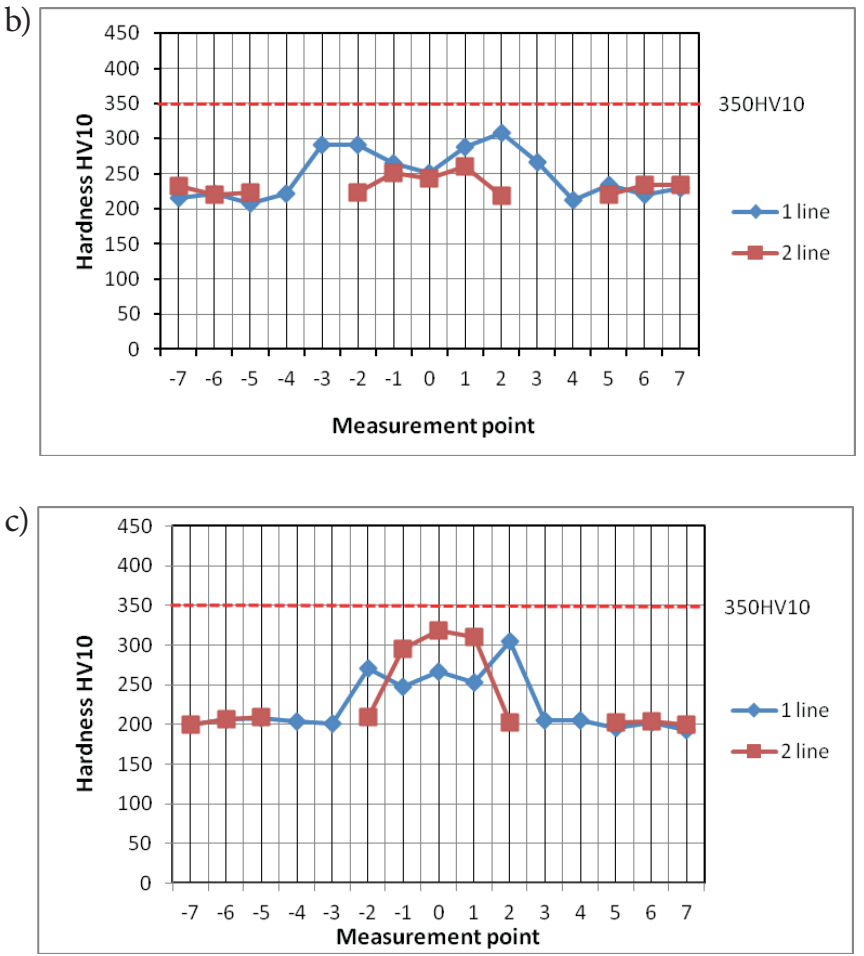

Fig. 8. Distribution of HV10 hardness values along the measurement lines 1 and 2 for the welded joints of the pipes with insulation coating : a) $C 1, b) C 2$, c) $\mathrm{C} 3$

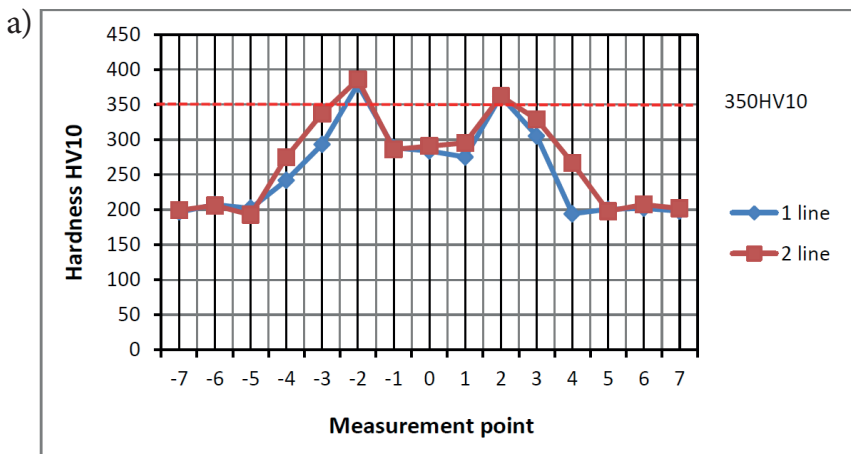


b)

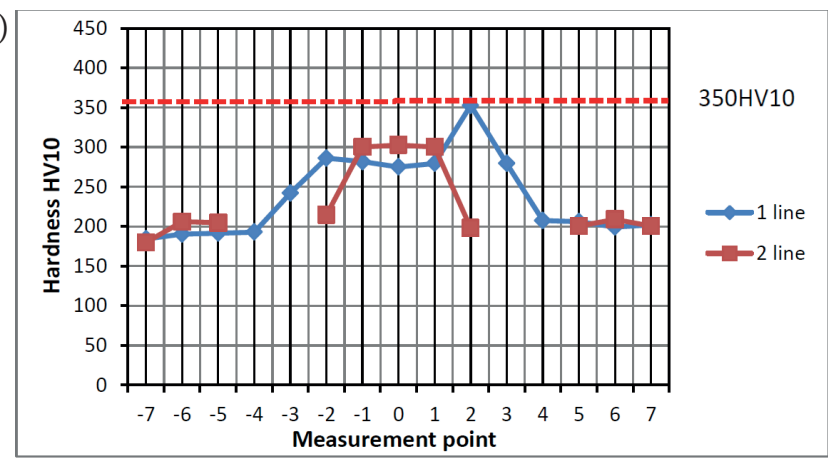

c)

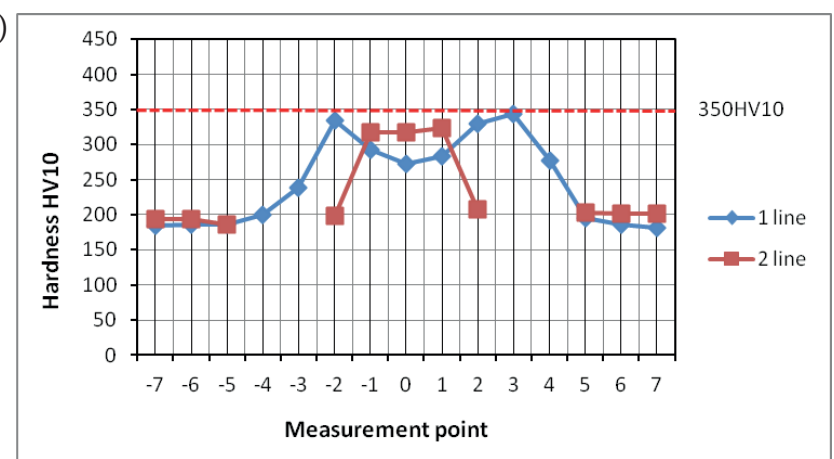

Fig. 9. Distribution of HV10 hardness values along the measurement lines 1 and 2 for the welded joints of the pipes without insulation coating: a) $W 1, b) W 2, c) W 3$

\section{SUMMARY}

The results of the conducted research show that it is possible to perform repair of cracks and fill-up corrosion wear in the pipeline made of API 5L X65M steel, by means of wet welding with the use of covered electrodes both in the case of insulated pipes and those without insulation coating.

The visual and penetrating tests showed that the applied welding procedure made it possible to obtain welded joints of a correct and symmetrical structure and relatively smooth face. The macroscopic examinations did not disclose any welding defects typical for underwater wet welding with the use of covered electrodes, such as non-metallic inclusions, cracks, pores, incomplete fusion.

During microscopic examinations, a growth of grain size in the HAZ of the joints, proportional to the heat input, was observed. In the HAZ of two specimens without insulation (W1 and W2) cold cracks were found. The cold cracks run across crystals through brittle areas of the HAZ. It was caused due to the following factors : the relatively high value of carbon equivalent of the steel $(0,41 \%)$, high cooling rate of the joint as well as high level of diffusible hydrogen in the welded joint. On the basis of the earlier conducted tests $[16,21]$ it may be assessed that the diffusible hydrogen content in the deposited metal exceeded $35 \mathrm{ml} / 100 \mathrm{~g}$. Presence of polymer insulation was conducive to the lowering of width of the HAZ. Any distinct effect of heat input during welding (within the range of $1.24-1.52 \mathrm{~kJ} / \mathrm{mm}$ ) on maximum hardness in the HAZ of the joints, was not observed.

It is worth stressing that changes in amount of introduced heat are limited for the reason of necessity of obtaining correct geometry of the joints. However, a distinct decrease in maximum hardness of the HAZ (below assumed in the DNV-OS-C401 standard criterion) was revealed in the joints of polymer insulated pipes, It may be expected that in the case of welding elements of a greater thickness, which requires to use multi-pass technique, a drop in maximum hardness of the HAZ, resulting from the phenomenon of tempering, would occur [27].

\section{CONCLUSIONS}

On the basis of an analysis of the results of the performed research, the following conclusions may be drawn:

1. It was proved that it is possible to repair cracks and fill-up corrosion wear in a pipeline made of API 5L X65M steel by using wet welding with covered electrodes.

2. Within the scope of the research no distinct effect of heat input on maximum hardness in the HAZ of the tested joints was observed.

3. Removal of the polymer insulation resulted in increasing of maximum hardness in the HAZ and occurrence of cold cracks in the HAZ.

\section{BIBLIOGRAPHY}

1. Ersdal G., Sharp J., Galbraith D.: Ageing accidents: suggestion for a definition and examples from damaged platforms. ASME 2014 33rd International Conference on Ocean, Offshore and Arctic Engineering, OMAE 201423674, pp. 1-9.

2. Ismail Z., Kong K.K., Othman S.Z., Law K.H., Khoo S.Y., Ong Z.C., Shirazi S.M.: Evaluating accidents in the offshore drilling of petroleum. Regional picture and reducing impact. Measurement, 51, 2014, pp. 18-33.

3. Rowe M., Liu S.: Recent developments in underwater wet welding. Science and Technology of Welding and Joining, 6(6), 2001, pp. 387-396.

4. Kozak J., Górski Z.: Fatigue strength determination of ship structural joints. Polish Maritime Research, 18(2), 2011, pp. 28-36.

5. Szlapczynski R., Szlapczynska J.: An analysis of domainbased ship collision risk parameters. Ocean Engineering, 126, 2016, pp. 47-56.

6. Jakubowski M.: Influence of pitting corrosion on fatigue and corrosion fatigue of ship structures. Part I Pitting corrosion of ship structures. Polish Maritime Research, 21(1), 2013, pp. 62-69. 
7. AWS D3.6M: 2010: Specification for underwater welding. American Welding Society, Miami, USA 2010.

8. Kong X., Li C., Zou Y., Hu Y.: Measurement and analysis of the diffusible hydrogen in underwater wet welding joint. MATEC Web of Conferences 39, 2016, pp. 1-5.

9. Rogalski G., Łabanowski J., Fydrych D., Tomków J.: Beadon-plate welding on S235JR steel by underwater local dry chamber process. Polish Maritime Research, 21(2), 2014, pp. 58-64.

10. Łabanowski J., Prokop-Strzelczyńska K., Rogalski G., Fydrych D.: The effect of wet underwater welding on cold cracking susceptibility of duplex stainless steel. Advances in Materials Science, 16(2), 2016, pp. 68-77.

11. Gao W., Wang D., Cheng F., Di X., Deng C., Xu W.: Microstructural and mechanical performance of underwater wet welded S355 steel. Journal of Materials Processing Technology, 238, 2016, pp. 333-340.

12. Garašić I., Kralj S., Kožuh Z., Pacak M.: Analysis of underwater repair technology on the jack-up platform spud can. Brodogradnja, 61(2), 2010, pp. 153-160.

13. Arias A.R., Bracarense A.Q.: Velocidade de propagação de trinca por fadiga de soldas subaquáticas molhadas: avaliação fora da água. Soldagem \& Inspeção, 20(4), 2015, pp. 403-411.

14. Silva L.F., Dos Santos V.R., Paciornik S., Mertens J.C.E., Chawla N.: Multiscale 3D characterization of discontinuities in underwater wet welds. Materials Characterization, 107, 2015, pp. 358-366.

15. Gao W., Wang D., Cheng F., Deng C., Liu Y., Xu W.: Enhancement of the fatigue strength of underwater wet welds by grinding and ultrasonic impact treatment. Journal of Materials Processing Technology, 223, 2015, pp. 305-312.

16. Fydrych D., Świerczyńska A., Rogalski G.: Effect of underwater wet welding conditions on the diffusible hydrogen content in deposited metal. Metallurgia Italiana, 107(11/12), 2015, pp. 55-60.

17. Maksimov S.Y.: Underwater arc welding of higher strength low-alloy steels. Welding International, 24(6), 2010, pp. 49-454.

18. Padhy G. K., Ramasubbu V., Murugesan N., Remash C., Albert S.K.: Effect of preheat and post-heating on diffusible hydrogen content of welds. Science and Technology of Welding and Joining, 17(5), 2012, pp. 408-413.
19. Pańcikiewicz K., Zielińska-Lipiec A., Tasak E.: Cracking of high-strength steel welded joints. Advances in Materials Science, 13(3), 2013, pp. 76-85.

20. Pandey C., Saini N., Mahapatra M.M., Kumar P.: Hydrogen induced cold cracking of creep resistant ferritic $P 91$ steel for different diffusible hydrogen levels in deposited metal. International Journal of Hydrogen Energy, 41(39), 2016, pp. 17695-17712.

21. Fydrych D, Łabanowski J., Rogalski G.: Weldability of high strength steels in wet welding conditions. Polish Maritime Research, 20(2), 2013, pp. 67-73.

22. Nowacki J., Sajek A., Matkowski P.: The influence of welding heat input on the microstructure of joints of S1100QL steel in one-pass welding. Archives of Civil and Mechanical Engineering, 16(4), 2016, pp. 777-783.

23. Zieliński A., Sobieszczyk S.: Hydrogen-enhanced degradation and oxide effects in zirconium alloys for nuclear applications. International Journal of Hydrogen Energy, 36(14), 2011, pp. 8619-8629.

24. Guo N., Liu D., Gu W., Li H., Feng J.: Effect of Ni on microstructure and mechanical properties of underwater wet welding joint. Materials \& Design, 77, 2015, pp. 25-31.

25. Yin Y., Yang X., Cui L., Cao J., Xu W.: Microstructure and mechanical properties of underwater friction taper plug weld on X65 steel with carbon and stainless steel plugs. Science and Technology of Welding and Joining, 21(4), 2016, pp. 259-266.

26. Wang F., Yang X., Cui L., Yin Y.: Fabricating defect-free API X65 steel welds in underwater wet condition with friction taper plug welding. Materials and Manufacturing Processes, 31(16), 2016, pp. 2123-2129.

27. Fydrych D., Świerczyńska A., Rogalski G., Łabanowski J.: Temper bead welding of S420G2+M steel in water environment. Advances in Materials Science, 16(4), 2016, pp. 5-16.

\section{CONTACT WITH THE AUTHORS}

$$
\begin{aligned}
& \text { Grzegorz Rogalski } \\
& \text { Dariusz Fydrych } \\
& \text { Jerzy Łabanowski }
\end{aligned}
$$

Gdańsk University of Technology

Faculty of Mechanical Engineering

Poland

Corresponding author: grzrogal@pg.gda.pl 